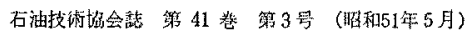

JOURNAL OF THE JAPANESE ASSOCIATION OF PETROLEUM TECHNOLOGISTS

VOL. 41 NO. 3 (May, 1967)

\title{
Alteration of Sandstone Intercalation in the Upper Nanakura Tuff Member Occurring at Futatsui District, Yamamoto-Gun, Akita Prefecture, Japan
}

\author{
Toshio NegishI \\ (Manuscript Received March 22, 1976)
}

\begin{abstract}
The Upper Nanakura tuff member is widely distributed at Futatsui area. This members mainly composed of vitric tuff and altered to clinoptilolite except of the sandstone intercalation. The sandstone is $1-2 \mathrm{~m}$ thick and contains mainly montmorillonite. Chemicaly this sandstone is abundant in $\mathrm{MgO}$ and $\mathrm{CaO}$, and tuff which contains clinoptilolite is abundant in $\mathrm{Na}_{2} \mathrm{O}$ and $\mathrm{K}_{2} \mathrm{O}$. From the laboratory experimental data montmorillonite is easily formed under $\mathrm{Mg}$ environment. So the formation of montmorillonite in sandstone intercalation of vitric tuff is supposed to be depended on some affection of $\mathrm{Mg}$ rich solution after origination of clinoptilolite by the low grade metamorphism. The solution passed easily through the sandstone intercalation because of better porosity and permeability than tuff, so $\mathrm{Mg}$ addition was occurred only in sandstone.
\end{abstract}

\section{Introduction}

The vitric tuff widely distributed in Futatsui district, Akita prefecture, generally contains volcanic glass and clinoptilolite and called Upper Nanakura tuff member. These minerals co-exist with montmorillonite in some parts. Clinoptilolite found in this area is thought to be the alteration materials of volcanic glass by the low grade metamorphism, so it is reasonable to think that there are close relations between the mineral assemblage and geological formation as reported by many authers (Yoshimura, 1961, 1964; Nakajima and Koizumi, 1962; Negishi, 1967; Utada, 1970; Aoyagi, et a1., 1975).

But the regularity of the mineral assemblage is sometimes disturbed by the local volcanic activities or ore solutions (Sumi, 1968; Honda and Muffler, 1970; Negishi, 1970), so the geological formation does not show the close relation with the mineral assemblage in such active areas. Futatsui area is far from such active area as Odate Kuroko area or Hachimantai

* Sumitomo Petroleum Development Co., Ltd. Lima office Las Magnolias 841, Office 205, San Isidro, Lima PERU active volcanic area, and it is thought that the mineral assemblage of this area is correspond to "stage 1" which is established by Coombs, et al., as zeolite facies (Coombs, et al., 1954; Seki, 1968; Honda and Negishi, 1968).

The Upper Nanakura tuff member is mainly composed of vitric tuff associated with thin intercalations of tuffaceous sandstone and mudstone. In Futatsui area, mineral assemblage shows some irregularity according to its mother rock. Tuff contains mainly clinoptilolite, sandstone which is intercalation of tuff contains much more montmorillonite than clinoptilolite and $\mathrm{mu}$ dstone which is also intercalation of tuff contains clinoptilolite. The chemical composition of those rocks shows somewhat difference depending on the rocks and minerals contained. Although tuff which contains clinoptilolite is abundant in $\mathrm{Na}$ and $\mathrm{K}$, sandstone which contains montmorillonite is abundant in $\mathrm{Mg}$ and $\mathrm{Ca}$, and mudstone show the same chemical properties as tuff.

In this paper, as to the above mentioned irr egularity of the mineral assemblage seen in the 
intercalation of sandstone, the cause was discussed in the view point of the chemical properties and physical properties such as porosity and permeability of the mother rocks.

The writer would like to express his deep gratitude to Prof. T. Sudo and Assoc. Prof. S. Shimoda, Tokyo University of Education and Prof. S. Honda, University of Akita, for their kind suggestions to this study.

\section{General Geology}

Pliocene pyroclastic rocks, (Maiya, Saito, and Sato, 1976), composed mairly of vitric tuffs, are widely distributed at Futatsui, and called Upper Nanakura tulf member. The volcanic glass in the rocks is wholly altered to clinoptilolite, except of the sandstone intercalations.

The tuffs contain various sizes of pumice and glass which are altered to zeolite by devitrification.

The occurrence of the specimens which are discussed in this paper showed above mentioned feature and were collected in limited area near Futatsui-machi (Honda and Negishi, 1967).

The geological structure of the area where the specimens were collected is NE.SW in strike and $30^{\circ}-35^{\circ} \mathrm{E}$ in dipping. The thickness of the tuff is about $80 \mathrm{~m}$. The tuff shows white yellow and light green color, and various type of rocks such as pumice tuff, silty tuff and sandy tuff were seen, and inclined various size of pumice $(\mathrm{cm}-\mathrm{mm})$. The pumice in the rocks wholly altered to zeolite and montmorillonite, and some intercalation of sandstone and mudstone (tuffaceous) are seen and they have generally about 1-2 m thickness.

The microscopic observation of the tuff shows commonly vitroclastic texture, and there are many pseudomorphs of pumices and glasses which altered to clinoptilolite. Many small automorphic crystals $(0.05 \mathrm{~mm})$ are seen in the center of the cavity. Small amount of quartz, feldspars, biotites and hornblendes are seen as phenocrysts. Quartz commonly shows corroded forms. In addition, greenish colored spotted mineral which is thought to be ceradonite is seen. The following sample were collected from various kind of rocks and studied by X-ray analysis and chemical analysis.

Fig. 1 The idealized sketch map of the sample localities (This map is highly idealized and does not show precise geological feature, sampling points and scale).

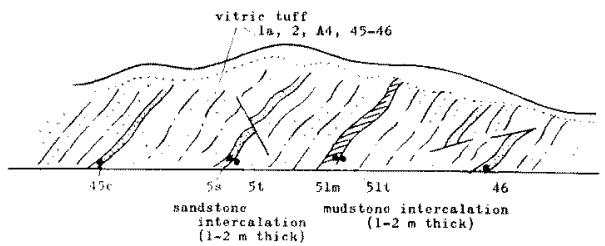

tuff contains clinoptilolite; $1 \mathrm{a}, 2, \mathrm{~A}-4,45-46$ $5 \mathrm{t}, 51 \mathrm{t}$.

tuff contains volcanic glass; $3,45 \mathrm{~d}$. mudstone contains clinoptilolite; $51 \mathrm{~m}$.

sandstone contains montmorillonite; $45 \mathrm{c}, 46$, $5 s$.

As shown in Fig. 1, mudstone and sandstone are very tuffaceous, and they are the intercalations of the tuff. The specimens $51 \mathrm{~m}$ and $51 t, 5 t$ and $5 s$, occurred with each other within about $50 \mathrm{~cm}$ distance.

\section{Mineral Assemblages}

The $\mathrm{X}$-ray powder pattern is shown in Fig. 2 as to the specimens taken from different localities and rocks of the upper Nanakura tuff member (specimens 1a, 2, A-4, 45-46 show same $X$-ray pattern as specimen $5 t$, so their patterns were omitted). It is clearly seen that tuff and mudstone contain mainly clinoptilolite, and sandstone contains much more montmorillonite than clinoptilolite. The specimen 3 and $45 \mathrm{~d}$ are mainly composed of unaltered volcanic glass. The specimen occurred at the upper part of this member.

As shown in Fig. 1, specimen $5 \mathrm{~s}$ and $5 \mathrm{t}$ is very closely occurred with each other, and specimen $51 \mathrm{~m}$ and $51 \mathrm{t}$ is also same relation. The distance between $5 \mathrm{~s}$ and $5 \mathrm{t}$, and $51 \mathrm{~m}$ and $51 \mathrm{t}$ 
Fig. $2 \mathrm{X}$-ray powder patterns of the specimens collected at Futatsui.

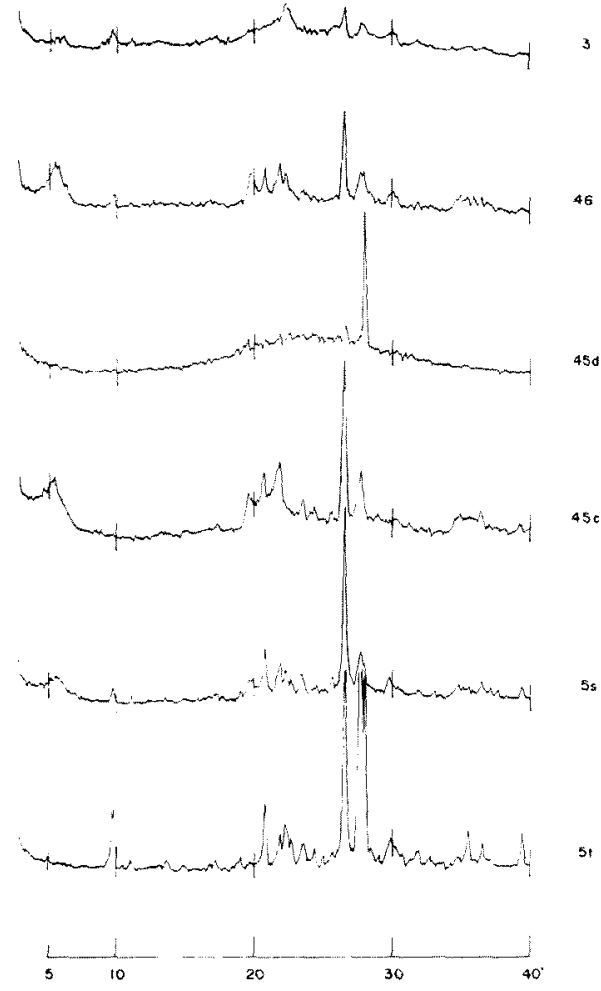

$\mathrm{s}$ within $50 \mathrm{~cm}$. But the mineral composition is apparently different. If the minerals is originated only by the low grade metamorphism, these specimens have to show same or very close mineral assemblage because the geological condition was almost same and was affected by the same condition of temperature and pressure. So the difference of mineral assemblage in these rocks due to another reason than simple low grade metamorphism.

\section{Chemical Compositions}

The specimens taken from different rocks and localities of the upper Nanakura tuff member were analysed chemically, and the relation between the alteration minerals contained and the mother rocks was discussed. The chemical analysis is shown in Table 1 . The relations of $\mathrm{MgO}, \mathrm{CaO}, \mathrm{Na}_{2} \mathrm{O}$, and $\mathrm{K}_{2} \mathrm{O}$ are shown in Fig. 3 and 4 . These figures clearly show the difference of the chemical compositions between montmorillonite-bearing rocks (sandstone) and clinoptilo. lite-bearing rocks (tuff and mudstone). The chemical composition of montmorillonite-bearing rocks is rich in $\mathrm{MgO}$ and $\mathrm{CaO}$, and the chemical composition of clinoptilolite-bearing rocks is rich in $\mathrm{Na}_{2} \mathrm{O}$ and $\mathrm{K}_{2} \mathrm{O}$. The tuff composed of unaltered volcanic glass has same chemical composition as clinoptilolite-bearing tuff and mudstone.

Specimens $5 \mathrm{~s}$ and $5 t$ are in contact with each other, and the former is a thin layer within

Table 1 Chernical composition of the specimens.

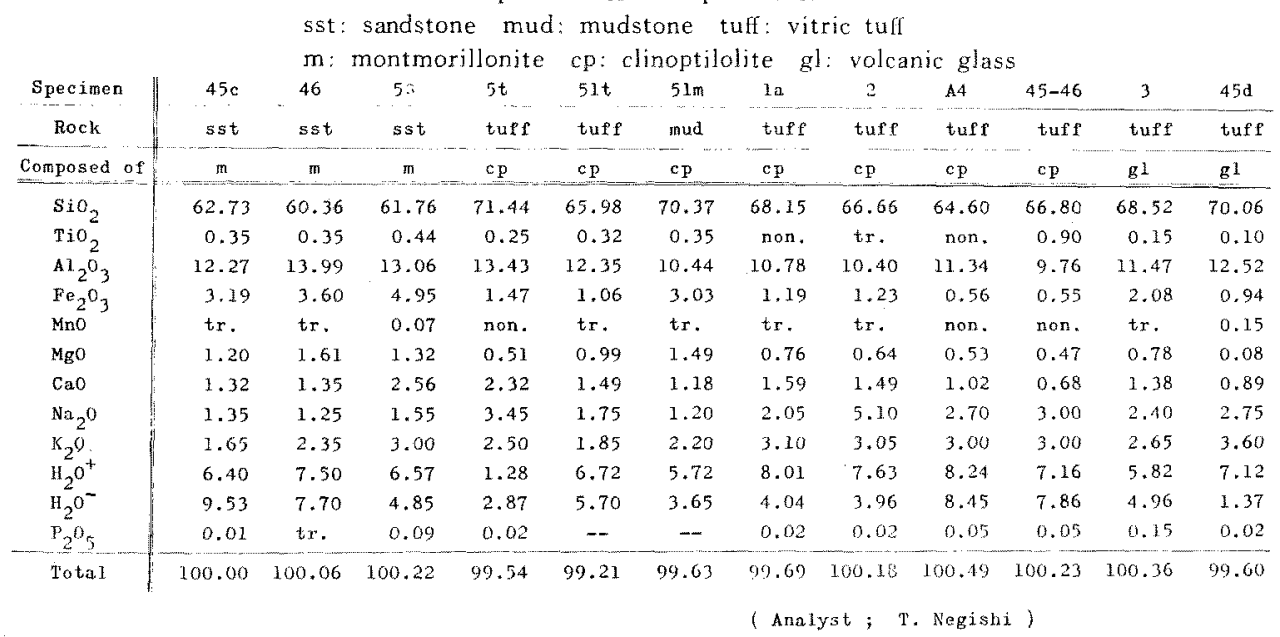


the latter. 5 s is sandstone and composed mainly of montmorillonite and $5 \mathrm{t}$ is tuff composed mainly of clinoptilolite. Specimen $51 \mathrm{t}$ and $51 \mathrm{~m}$ are also in contact with each other, and the latter is a thin layer within the former. Both specimens are composed mainly of clinoptilolite. The reason why montmorillonite occurs only in sandstone and clinoptilolite in tuff and mudstone is not clear, but it seems attributable to some local condition, not only to the low grade metamorphism or diagenesis.

\section{Discussions}

The alteration minerals in Upper Nanakura tuff member were composed of clinoptilolite and montmorillonite, which were altered from volcanic glass. There are close relations between the alteration minerals contained and the mo. ther rocks, and there are close chemical relations between the alterations minerals and the mother rocks. Tuff and mudstone contain clinoptilolite and are abundant in $\mathrm{Na}_{2} \mathrm{O}+\mathrm{K}_{2} \mathrm{O}$. On the other hand, sandstone which is intercalation in tuff contains montmorillonit and is abundant in $\mathrm{MgO}+\mathrm{CaO}$. Tuff which contains unaltered volcanic glass shows the same chemical properties as clinoptilolite bearing tuff and mudstone. So only sandstone is different in altered mineral contained and in chemical com. position.

These rocks occur very close localities, especially specimen $51 \mathrm{~m}$ and $51 \mathrm{t}$, and $5 \mathrm{t}$ and 5 s occur within $50 \mathrm{~cm}$ distance. So the occurrence of montmorillonite in sandstone is not due to only the low grade metamorphism. The cause seems to depend on some additional local phenomena.

\section{1) Effect of $\mathrm{Mg}$}

As seen in Fig. 3 and 4, distribution area of chemical composition of montmorillonite-bearing rocks is abundant in $\mathrm{MgO}+\mathrm{CaO}$. Montmorillonite is thought to have been altered from volcanic glass added by MgO (Iijima, 1972) and clinoptilolite-bearing tuff is easily altered to
Fig. 3 Fields of the chemical composition of clinoptilolite bearing-tuffs, -mudstone and montmorillonite bearing sandstones plotted on the triangular diagram of $\mathrm{MgO}+\mathrm{CaO}-$ $\mathrm{Na}_{2} \mathrm{O}-\mathrm{K}_{2} \mathrm{O}$

Specimen mainly composed of;

- clinoptilolite,

volcanic glass,

- montmorillonite

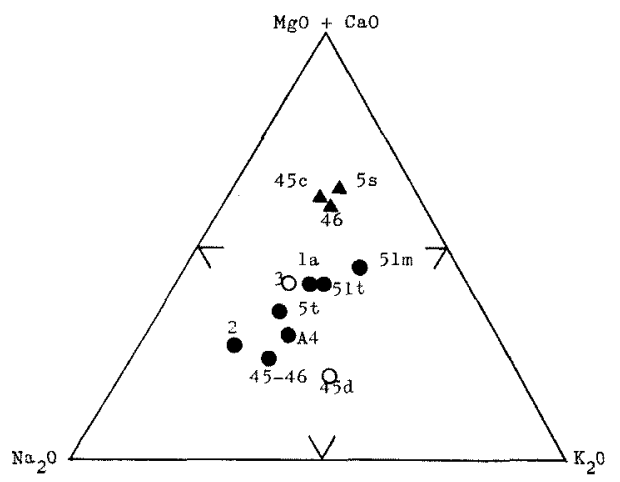

Fig. 4 Triangular diagram of $\mathrm{Na}_{2} \mathrm{O}+\mathrm{K}_{2} \mathrm{O}-\mathrm{CaO}$ $\mathrm{MgO}$. (symbols are same as Fig. 3)

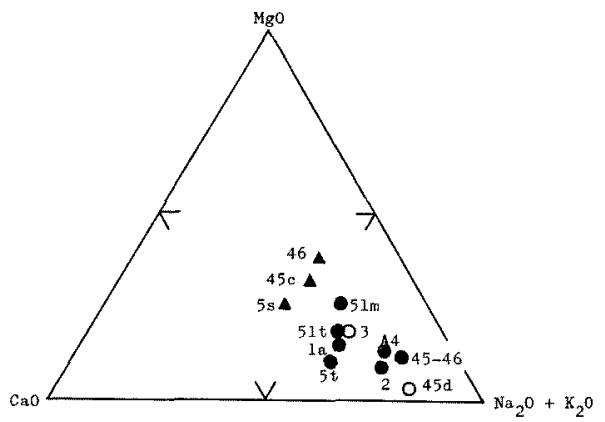

montmorillonite in $\mathrm{MgO}$ environments as mentioned in the following. So montmorillonite is thought to easily occur where $\mathrm{Mg}$ component is added. The writer synthesized the zeolite $\mathrm{X}$ from clinoptilolite bearing tuff by the treatment with sodium hydrooxide under normal condition $\left(1 \mathrm{~atm} .100^{\circ} \mathrm{C}\right.$ ) (Negishi, $1970 \mathrm{~b}$ ). In the same study, montmorillonite was synthesized under high pressure $\left(300^{\circ} \mathrm{C}, 110 \mathrm{~atm}\right.$.) by treated with $\mathrm{Mg}$-hydrooxide (Fig. 5). In the same condition $\left(300^{\circ} \mathrm{C}, 110 \mathrm{~atm}.\right)$, when the sample was treated with Na-hydrooxide, zeolite, such kind of analcine, was formed. 
Fig. $5 \mathrm{X}$-ray powder patterns of the synthesized montmorillonite from clinoptilolte-bearing tuff in the environment of $\mathrm{Mg}$.

Orientated: orientated on the glass slide. $\mathrm{E}-\mathrm{G}$ : treated with ethylen glycol.

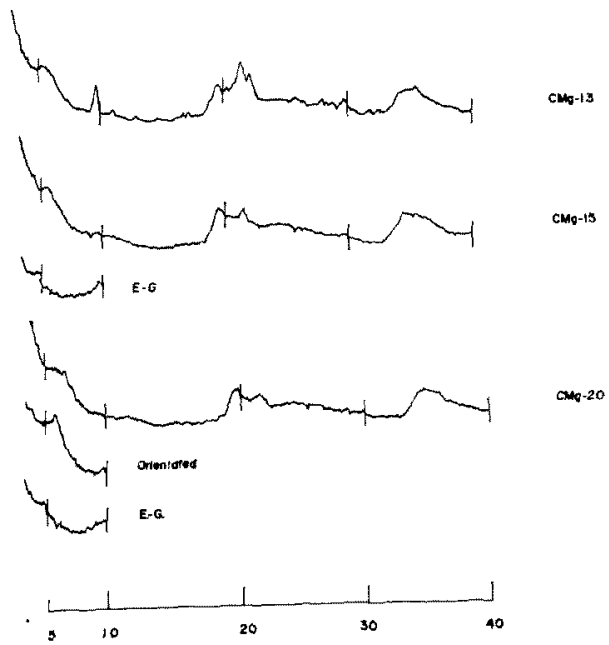

This show that montmorillonite easily formed under $\mathrm{Mg}$ environment and zeolite was formed under $\mathrm{Na}$ environment. This fact is not contradictory to the field data seen in Futatsui district.

2) The Physical property of sandstone

The difference between sandstone and tuff is seen in the value of porosity and peameability.

Table 2 Porosity and permeability of tuff and sandstone (after Sekiyu Kogyo Benran, 1963)

\begin{tabular}{l||cc} 
& Tabase tuff & rabase sandstone \\
\hline Porosity (曻) & $25.5-25.6$ & $35-40$ \\
Perneability ( nd ) & $4.9-4.5$ & $160-600$
\end{tabular}

The data of porosity and permeability is shown in Table 2. Yabase tuff and Yabase sandstone are correlated geologically to Upper Nanakura tuff member, so the physical nature is thought to be almost same as tuff and sandstone of the Nanakura member in Futatsui area.

The value of porosity in tuff show $25 \%$, and sandstone show $35-40 \%$. As to permeability, tuff has $5^{\mathrm{md}}$, but sandstone has $160-600^{\mathrm{md}}$. So the permeability of sandstone is 50-100 times as much as the tuff. Mudstone is more compact than tuff. These data show that sandstone is thinkable as a channel of some solution. If this solution was abundant in $\mathrm{MgO}$, sandstone was much more affected by $\mathrm{MgO}$ than tuff and mudstone.

It was not clear whether there was such activity of solution in true, but if such kind of solution existed, it is obviously said that sandstone was much more affected by such solution than tuff or mudstone, and $\mathrm{Mg}$-component was selectively added to only sandstone.

Honda (1975) also discussed the similar mode of occurrense of clinoptilolite and montmorillo. nite in Wyoming Bentonite (U.S.A), and throught some reaction of pore water for the secondary formation of montmorillonite in porous part of the deposit.

3) The difference between $P_{H: O}$ and $P_{\text {joad }}$

The porous part which is surrounding by compact materials show the different condition of $\mathrm{P}_{\mathrm{H}_{2} \mathrm{O}}>\mathrm{P}_{\mathrm{lod}}$, and the local irregularity of the mineral assemblage is often seen in such porous part (Coombs, et al., 1959, Nakajima and Tanaka, 1967). In Katsurane area, which is 40 $\mathrm{Km}$ S-E from Futatsui, analcime is seen in the porous part of tuff, and surrounding tuff is generally composed of cliniptilolite (Negishi, unpublished). This reason through to be the difference of $\mathrm{P}_{\mathrm{H}_{2} \mathrm{O}}$ and $\mathrm{P}_{\text {load }}$ in sandy part. The origin of montmorillonite in sandstone in Futatsui district can be thought to depend on such reason. But the ideal system of the condition of $\mathrm{P}_{\mathrm{H}: \mathrm{O}}<\mathrm{P}_{\text {load }}$ is closed system, and the Futatsui sandstone have some difficulties to be thought as closed system, because of having about 1-2 $\mathrm{m}$ thickness and some continuities. Moreover, if sandstone was situated in closed system, it is difficult to think that $\mathrm{Mg}$ component was added only to sandstone selectively.

\section{Conclusion}

The clinoptilolite bearing tuff is widely distributed in Futatsui district, Yamamoto gun, Akita Prefecture. The tuff is called Upper Nanakura 
tuff. In this tuff bed, there are some intercalation of sandstone and mudstone having $1-2 \mathrm{~m}$ thickness. The sandstone is tuffaceous and co. ntain much more altered montmorillonite than clinoptilolite.

The chemical composition of sandstone show high content of $\mathrm{MgO}$, and tuff and mudstone does not show the same native as sandstone, and its chemical nature is similar to the unaltered volcanic glass which is thought to be original rocks of these altered rocks. The chemical relation between the alteration minerals contained and the mother rocks are clearly recognized in these tuff, mudstone and sand. stone.

If these altered minerals were originated by the low grade metamorphism, it is reasonable to say that they show similar mineral assemblage and chemical properties. But in this area whole data do not show such close relation, and the irregularity of mineral assemblage in different mother rocks was discussed and will be concluded as follows.

Firstly this area was widely affected by low grade metamorphism with increasing the burial depth, and originated authigenetic altered minerals, especially clinoptilolite from volcanic glass.

Secondary, some activities of $\mathrm{Mg}$-solution happened, and this solution mainly passed through sandstone intercalation because of good porosity and permeability. And montmorillonite originated in only sandstone being affected by Mg-solution.

This presumption was supported by the experimentation of the laboratory. Although it is impossible to confirm that such $\mathrm{Mg}$-solution really existed, comparing with the chemical composition of original rocks, only the sandstone is apparently added by $\mathrm{Mg}$-component.

\section{References}

Aoyagi, K, et al. (1975), Clay mineral in the sedimentary rocks of the oil-bearing Tertiary and $\mathrm{Cr}$ etaceous in Japan. Contribution Clay Mineralogy,
Prof. T. Sudo, 167-172.

Coombs, et al. (1959), The zeolite facies with comments on the interpretation of hydrothermal syntheses. Geochim. Cosmochim., Acta, 17, 53-107.

Fujioka, K. and Yoshikawa, T. (1969), Zeolitic alteration of vitric tuffs in Akita oil field. Jour. Jap. Assoc. Petrol. Technol., 34, 145-154.

- and Sasaki, A. (1971), Zeolitic alteration of vitric tuffs in the Akita oil field, (Part 3) on the Noshiro sedimentary basin. Jour. Jap. Assoc. Petrol. Technol., 36, 127-135.

Honda, S. and Negishi, T. (1968), Clinoptilolite from Futatsui-machi, Yamamoto-gun, Akita Prefacture, Japan. Jour. Clay Scie. Soc. Jap., 7, 62-74.

-_ (1969), Fundamental Studies of the use of zeolite rock in Akita prefecture. Rep. Reser. Inst. Undergro. Resources Mini. Call. Akita Univ, No. $38,31-44$.

- and Muffer, L.J.P. (1970), Hydrothermal alteration in core from from research drill hole Y-1, Upper Geyser Basin, Yellowstone Park, Wyoming. Amer Mineral., 1714-1737.

- (1975), Some findings on Bentnite from near Kaycee, Wyoming, U.S.A. and on the contents of montmorillonite. Contribution to Clay Mineralogy, Prof. T. Sudo, 108-114.

Iijima, A. (1972), Argillaceous and zeolitic alteration zones surrounding Kuroko (black ore) deposits in Odate district of Akita prefecture. Jour. Socie. Mini. Geologist. Jap., 22, 1-20.

Maiya, S. Saito, T., and Sato, T. (1976), Late Cenozoic planktonic foraminiferal biostratigraphy of northwest Pacific sedimentary sequences. Progress in micropaleontology, pp. 395-422, pls. 1-6.

Nakajima, W. and Koizumi, M. (1966), On the chemical composition of analcine from the low grade metamorphic rocks in Japan. Jout. Geo. Soc. Jap., 72, 517-521.

- and Tanaka, K. (1967), Zeolite bearing tuff from the Izumi group in the central part of the Izumi mountain range, southwest Japan, with reference to mordenite-bearing tuffs and laumontite tuffs. Jour. Geol. Soc. Jap., 73, 237-245.

Negishi, T. (1967), Mineral assemblage of the Miocene pyroclastic rocks in the environs of Minakami City, Gunma Pref. Japan. Jour. Geol. Soc. Jap., 
$73,407-418$.

- (1970a), Laumontite-tuff from Kozawa, Iwanai district, Hokkaido. Jour. Clay Scie. Soc. Jap., $10,110-116$.

- and Nakamura, H. (1970 b), Synthesis of the zeolite type $\mathrm{X}$ from clinoptilolite bearing tuffs by the treatment with sodium hydrooxide. Jour. Min. Soc. Jap., 10, 72-81.

Seki, Y. (1968), A consideration to the zeolite facies metamorphism in the Green Tuff region of Japan. Jour. Assoc. Jap. Min. Petr. Econ. Geol, 59, 118-123.

Sumi, K. (1968), Hydrothermal rock alteration of the Matsukawa geothermal area, northeast Japan. Geol. Surv. Japan Rept., No. 225, 1-44.

Yoshimura, T. (1961), Zeolite in the Miocene pyroclastic rocks in the Oshima-Fukushima district, southern Hokkaido. Jour. Geol. Soci Jap., 67, 578-583.

- (1964), Zeolites in the green tuff formation. Jour. Min. Soc. Jap., 7, 45-50.

Utada, M. (1970), Occurrence and distribution of authigenetic zeolites in the Neogene pyroclastic rocks in Japan. Sci. Paper of Col. Gen Educ. Univ. Tokyo, 20, 191-762.

\section{要旨}

秋田県山本郡一ツ井地力の上部七应 凝灰岩の砂岩夾在層の変質について

根岸 敏雄

秋田罧山本郡二ッ井地方には，上部七幽凝兏䇹と呼ば

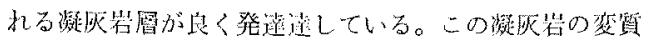
銨物は斜プチロロ汫石が主であり，埋没沈下による低度 変成作用和よび続成作用で形成されたと考党られてい

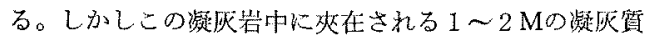
仯岩には，斜プチロル沜石が見られず，主としてモンモ

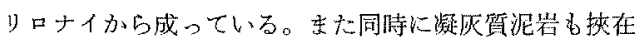

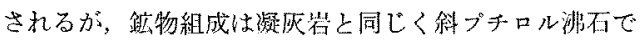
ある。これらの母岩と含まれる变筧鉱物和よび化学組成 の間には舆味ある関倸が楒められた。すなわち䣄プチロ 儿渄石を含さ中のは $\mathrm{Na}_{2} \mathrm{O}$ と $\mathrm{K}_{2} \mathrm{O}$ に富み，モンモり ロナイトを含むものは $\mathrm{MgO} と \mathrm{CaO}$ に蜜えでいた。 またこれらの変筫岩の原署と考克られる未变質の火山ガ ラスより成る凝灰岩が，これらの地層の上部に存在する が，その化学組成は斜プチロル沸石を含むものに近い值 を示した。。もしこれらの変質が低度变成作用あるいは穁 成作用だけからであるなら，これらの作用は比較的広域 的であることから，母岩が異なるとはい党鉱物組成も化

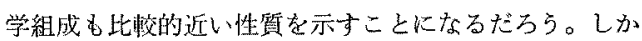
るにこの㘯区で㤬，砂岩挾在煟だけが翼なった性質を示

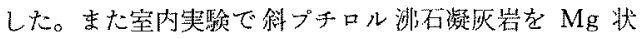
態下で处理するとモンモリナイトが形成され，同一条件 でる $\mathrm{Na}$ 状態では沸石（方別石）が形成された。

以上のことがら，この地区に見ら机る砂砦挟在風のみ に見られるモンモりロナイトの変丝は，何らかの2次的 な $\mathrm{Mg}$ の添加があったとすると容易飞视明される。す なわり何らかの Mg 溶液の活動があり，をれが選択的 にポロシティー拈よびパーミアビりティーの良い仯岩中 をより多く通過し，Mg の添加が砂岩に集中的におこ り，火山ガラスあるいはすでに形成されていた斜プチロ ル沸石か゚モンモりロナイトに变化したと考えられた。 